\title{
Learn Energy Sources with Interactive Learning Multimedia
}

\author{
* L. A. Suwiantini1 1, I. N. Jampel2, I. G. Astawan ${ }^{3}$
}

1,3 Program Studi Pendidikan Guru Sekolah Dasar, Universitas Pendidikan Ganesha, Singaraja, Indonesia

${ }^{2}$ Program Studi Teknologi Pendidikan, Universitas Pendidikan Ganesha, Singaraja, Indonesia

\section{A R T I C L E I N F O}

Article history:

Received in revised form

8 January 2021

Accepted 18 January 2021

Available online 25

February 2021

Kata Kunci:

Sumber, Energi,

Multimedia, Interaktif

Keywords:

Source, Energy, Multimedia,

Interactive

\begin{abstract}
A B S T R A K
Rendahnya motivasi belajar siswa karena penggunaan media pembelajaran khususnya pada pembelajaran IPA masih belum optimal. Penelitian ini bertujuan untuk menciptakan media pembelajaran berbasis multimedia interaktif pada topik sumber energi kelas IV sekolah dasar. Penelitian ini merupakan penelitian pengembangan dengan menggunakan model ADDIE. Pada penelitian ini tahap implementasi dan tahap evaluasi tidak dilaksanakan karena keterbatasan waktu dan kondisi saat ini sedang terjadi pandemi covid19. Subjek penelitian ini adalah media pembelajaran berbasis multimedia interaktif yang di nilai oleh 2 orang ahli materi, 2 orang ahli media, 2 orang ahli desain dan 2 orang ahli praktisi serta uji perorangan oleh 3 orang siswa dan uji kelompok kecil oleh 6 orang siswa. dan objek penelitian ini adalah validitas media pembelajaran berbasis
\end{abstract} multimedia interaktif. Metode pengumpulan data yang digunakan pada penelitian ini adalah metode kuisioner. Teknik analisis data yang digunakan pada penelitian ini adalah analisis deskriptif kualitatif dan kuantitatif. Hasil penelitian menunjukkan kualitas media dari 1) ahli materi berada pada nilai 94,63\% (sangat baik). 2) Ahli media berada pada nilai 93,33\% (sangat baik). 3) ahli desain berada pada nilai 91,66\% (sangat baik). 4) Ahli Praktisi berada pada nilai 91,66\% (sangat baik). 5) uji coba perorangan berada pada nilai $96,11 \%$ (sangat baik). 6) Uji coba kelompok kecil berada pada nilai sebesar 94,77\% (sangat baik). Jadi media pembelajaran berbasis multimedia interaktif yang dihasilkan berkualifikasi sangat baik dan layak untuk digunakan dalam proses belajar mengajar.

\begin{abstract}
A B S T R A C T
The low learning motivation of students is caused by the use of learning media, especially in science learning which is still not optimal. This study aims to create interactive multimedia-based learning media on the topic of energy sources for grade IV elementary schools. This research is development research using the ADDIE model. In this study, the implementation and evaluation stages were not carried out due to time constraints and the current condition of the COVID-19 pandemic. The subject of this research is interactive multimedia-based learning media which is assessed by 2 material experts, 2 media experts, 2 design experts, and 2 practitioner experts as well as individual testing by 3 students and small group testing by 6 students. and the object of this research is the validity of interactive multimedia-based learning media. The data collection method used in this research is the questionnaire method. The data analysis technique used in this research is descriptive qualitative and quantitative analysis. The results showed that the media quality of 1) material experts were at a value of $94.63 \%$ (very good). 2) Media experts are at a score of 93.33\% (very good). 3) design expert is at 91.66\% (very good). 4) Expert Practitioners are at a score of $91.66 \%$ (very good). 5) individual trials are at a value of $96.11 \%$ (very good). 6) The small group trial was at a value of $94.77 \%$ (very good). So the interactive multimedia-based learning media produced are very well qualified and worthy to be used in the teaching and learning process.
\end{abstract}

\section{Introduction}

Science learning is an important lesson to be taught to students. Natural science or science is the study of natural phenomena, living and non-living things and about life (Rahayu et al., 2012). Science learning should emphasize more on student activities during the learning process to create more meaningful learning for students (Fuadi et al., 2015). Science learning is expected to be able to develop students' thinking power and scientific attitude in solving problems they face and become a vehicle for 
students to get to know themselves and the environment around them. There is a need for more innovative teaching strategies so that the field of study can be well understood by students (Laksana, 2016). The curriculum, especially in science learning, is a description of the goals and competencies that are expected to be achieved after the learning activities. A teacher is expected to be able to create a learning atmosphere that is in accordance with the characteristics of students and the characteristics of the material presented in the form of a learning model equipped with learning resources and learning media that support (Irfan et al., 2019). The many scopes and abstract concepts become obstacles for students in studying science. The limitations of teaching materials in presenting science concepts do not help much in visualizing concepts so that they become more concrete (Putri, 2015). The importance of learning science requires teachers to be able to create a conducive learning atmosphere, a learning environment that allows students to gain learning experiences through positive interactions, both student-teacher interactions, and student-student interactions in order to achieve science learning objectives (Ariantini et al., 2017). Teachers must be able to shape students' learning motivation so that students are able to find satisfaction in learning in their school life (Yakovleva \& Goltsova, 2016). In addition, the teacher must also be able to provide understanding to students that allows students to carry out and practice the material they receive (Lewis, 2019). Planting science and technology learning can increase students' creativity, problem-solving skills and interest in the field of science, so it is necessary to integrate learning with technology by developing technology-assisted learning media such as internet access, computer use. gadgets and projector screens (Huang et al., 2020). Digital learning becomes innovative and creative learning in the school environment (Kornmann et al., 2016). The use of technology in education can change the traditional classroom climate, students who initially only hear, see and imitate what the teacher says but with technology students can obtain information through interactive media so that students can build more meaningful learning (Rante et al., 2013).

Problems that still occur in science learning are misconceptions in science learning, learning that is more teacher-centered, students have not had optimal opportunities to interact in the form of discussions with other students, in learning teachers do not use learning media (Ariantini et al., 2017). Lack of teacher readiness in facing development challenges and deepening knowledge (Gallagher, 2019) Elementary school students are not able to think abstractly (Ucus, 2015). Science learning contains many abstract concepts so that it is sometimes difficult for students to understand (Khan \& Masood, 2015; Laksana, 2016). Low students' metacognitive awareness and skills in understanding a concept (Lee \& Osman, 2012). Based on the results of observations and interviews with fourth grade teachers at SD Negeri 1 Gianyar, the implementation of learning is carried out by utilizing teacher books and the environment as a source of learning and learning tends to be more teacher-centered. In schools, facilities such as projectors and audio are provided for use in learning, but they are not used optimally. The use of school facilities as learning media is still not maximized so that students in the class show their disinterest when the teacher explains the subject matter. Students are less interested and motivated to learn so they do other activities (Irfan et al., 2019). Learning resources only come from student books and student worksheets that make students bored with learning and the material in student books that is still shallow makes students less understanding of the material presented (Riani et al., 2015). The existence of social inequality in the student environment in terms of the economy is a problem in the use of technology in learning (Paratore et al., 2016). Problems that occur if left unchecked will affect students' understanding of science learning and science learning outcomes.

The solution that can be done is to develop interactive multimedia-based learning media. Multimedia is one of the strategies in improving the quality of education and improving student performance (Abdulrahaman et al., 2020). Interactive multimedia is a learning tool or facility whose materials and methods and limitations are designed systematically and attractively to achieve learning objectives and competencies (Hernaningtyas et al., 2016). Interactive multimedia is very suitable for use in the learning process, one of which is science learning because of its wide scope, interactive multimedia makes it easier for students to understand the material in science learning (Widayat et al., 2014) In line with previous research, the results of the study state that interactive multimedia-based learning media are feasible to be used as learning facilities in schools (Pariartha et al., 2013). The results of further research stated that interactive multimedia-based learning media were in very good qualification and were suitable for use in learning (Hardhiyasa et al., 2013). The use of interactive multimedia-based learning media can improve student learning outcomes (Pujiastuti et al., 2014). The development of qualified interactive multimedia-based learning media is suitable for use in learning stated in the research (T. N. Akbar, 2016). Interactive multimedia-based learning media were responded positively by teachers and students and were suitable for use in learning (Sofyan et al., 2016). Effective interactive multimedia-based learning media to improve students' science learning outcomes (Saifudin et al., 2020; Setiawan et al., 2017). Interactive multimedia can improve student learning outcomes by achieving $100 \%$ classical completeness 
stated in the research (Widayat et al., 2014). So, Interactive Multimedia is suitable for use as a learning medium because it can improve students' understanding and learning outcomes, but from previous research, most interactive multimedia-based learning media are packaged using CDs so that they can only be accessed via computers. To overcome these shortcomings, interactive multimedia-based learning media were developed that can be accessed via computers or gadgets.

The interactive multimedia-based learning media that has been developed has advantages such as the media can be controlled directly by its users, both teachers and students. There is interaction between the user and the media because the media is equipped with several features or buttons to go to the desired media page. The material is equipped with examples in the form of illustrations to make it easier for students to understand the material. Interactive multimedia-based learning media can be accessed via computers or mobile phones because they can be shared using links. The development of interactive multimedia-based learning media on the topic of energy sources in grade IV Elementary School has never been developed so that interactive multimedia-based learning media is developed on the topic of energy sources for grade IV Elementary School. With interactive multimedia-based learning media, it can increase students' interest in learning. The purpose of this study was to develop interactive multimedia-based learning media on the topic of energy sources for class IV Elementary Schools whose validity was tested. The implication of this research is the existence of interactive multimedia-based learning media on the topic of valid elementary school fourth grade energy sources.

\section{Method}

This research is an interactive multimedia-based media development research with the model used as a reference is the ADDIE model (Analyze, Design. Development, Implementation, Evaluation). The ADDIE model contains 5 interconnected components, structured systematically, which means that from the first stage to the fifth stage, its application must be systematic, cannot be ordered randomly. these five stages or steps are very important Simple compared to other design models. The stages of the ADDIE model are the analysis phase (Analyze) which includes several activities, namely conducting needs analysis by conducting interviews and observations at SD Negeri 1 Gianyar, curriculum analysis is carried out by adjusting KD, indicators and learning objectives as well as material in student books, analyzing student characteristics This is done to determine the characteristics of students who will later use the media created and media analysis is carried out to determine the criteria for good media. The design stage (design) at this stage is the media design design, determining the layout of the media, the background display and the elements that exist in the media. The development stage at this stage is the development of interactive multimedia-based learning media on the topic of energy sources for class IV elementary schools according to the design that has been made and then consulted with the supervisor. After the media was consulted, it was continued by conducting an assessment by providing validation assessment instruments to four lecturers and two teachers.

The next stage after interactive multimedia was developed, product trials were carried out to three students in individual trials and six students in small group trials. The design of the trial carried out is a review from experts to determine the validity of the developed media and then analyzed based on the score obtained from the experts. The subject of the product trial is an interactive multimedia-based learning media on the topic of energy sources for grade IV elementary school. The object of the test is the validity of the developed interactive multimedia-based learning media. There are two types of data obtained from this study, namely qualitative data and quantitative data. Qualitative data is obtained through comments, suggestions and input provided by experts and quantitative data is obtained from assessment sheets or scores given by experts. The method used is a questionnaire. The instrument used is the Likert scale. Questionnaires were used to assess the validity of the developed interactive multimediabased learning media. In this study, the validity of the instrument can be ascertained by making an instrument grid. The instrument grid refers to development which consists of learning aspects, design aspects, media aspects and content aspects. Based on several aspects mentioned above, a grid of interactive multimedia-based learning media validation sheets can be made which is presented in Table 1.

Table 1. Interactive Multimedia Instruments Grid

\begin{tabular}{|c|c|c|c|c|}
\hline No & Aspect & Indicator & Number of Item & Total \\
\hline \multicolumn{5}{|c|}{ Material Experts } \\
\hline & & Competency compatibility & 1,2 & 2 \\
\hline 1 & Learning & Learning process & 3,4 & 2 \\
\hline & & Giving motivation & 5,6 & 2 \\
\hline
\end{tabular}




\begin{tabular}{|c|c|c|c|c|}
\hline No & Aspect & Indicator & Number of Item & Total \\
\hline \multirow{3}{*}{2} & \multirow{3}{*}{ Content } & Material quality & $7,8,9,10$ & 4 \\
\hline & & Material Selection & 11,12 & 2 \\
\hline & & Material Relevance & $13,14,15$ & 3 \\
\hline \multicolumn{5}{|c|}{ Media Experts } \\
\hline \multirow{3}{*}{3} & \multirow{3}{*}{ Media Quality } & Ease of use & $16,17,18$ & 3 \\
\hline & & Language Usage & 19,20 & 2 \\
\hline & & $\begin{array}{l}\text { Selection of background } \\
\text { music/sound }\end{array}$ & 21,22 & 2 \\
\hline \multirow{3}{*}{4} & \multirow{3}{*}{$\begin{array}{c}\text { Media } \\
\text { Visualization }\end{array}$} & Image quality & $23,24,25$ & 3 \\
\hline & & Layout & $26,27,28$ & 3 \\
\hline & & Illustration suitability & 29,30 & 2 \\
\hline \multicolumn{5}{|c|}{$\begin{array}{l}\text { Design Experts } \\
\end{array}$} \\
\hline \multirow{3}{*}{5} & \multirow{3}{*}{ Appearance } & Cover Design & $31,32,33,34,35$ & 5 \\
\hline & & Visual Design & $36,37,38,39,40$ & 5 \\
\hline & & Image Design & $41,42,43,44,45$ & 5 \\
\hline \multicolumn{5}{|c|}{ Small Group Trial } \\
\hline \multirow{5}{*}{6} & \multirow{5}{*}{$\begin{array}{c}\text { Media } \\
\text { Presentation }\end{array}$} & Ease of Use & $1,2,3,4,5$ & 5 \\
\hline & & Theory/Material & $6,7,8$ & 3 \\
\hline & & Display & $9,10,11$ & 3 \\
\hline & & Giving Motivation & 12,13 & 2 \\
\hline & & Language Usage & 14,15 & 2 \\
\hline
\end{tabular}

Before being tested in the study, the instrument used must be valid. In testing the validity of the content of the instrument, it is carried out by assessments carried out by experts (judges) by reviewing the instrument grid. Based on the content validity test, the content validity of interactive multimediabased learning media instruments from material experts was 0.93 and from media, design and small group test experts it was 1.00 . The results of the content validity test show that the content validity of the assessment instrument is in the very high category. After the content validity test was carried out, it was continued by measuring the constancy of the instrument using the percentage agreement. The results of the reliability test obtained $98.66 \%$ results with a very high degree of reliability. In this study, qualitative and quantitative descriptive data analysis methods and techniques were used. Qualitative descriptive data analysis in this study was conducted to process data in the form of input, comments and suggestions given by expert tests on the developed media. Quantitative descriptive data analysis was used to process the data obtained through a questionnaire in the form of scores. The formula used to calculate the percentage. In order to be able to make decisions and give meaning, the determination of the conversion level of achievement with a scale of five can be used which is presented in Table 2.

Table 2. Conversion of PAP Achievement Level with Five Scale

\begin{tabular}{cc}
\hline Achievement level (\%) & Predicate \\
\hline $90-100$ & Very Good \\
$80-89$ & Good \\
$65-79$ & Moderate \\
$55-64$ & Bad \\
$0-54$ & Very Bad \\
\hline & (Prabawa \& Restami, 2020)
\end{tabular}

\section{Result and Discussion}

Interactive multimedia on the topic of energy sources was developed based on the ADDIE model. This model was chosen because it has clear and systematic stages of learning development. The stages of this ADDIE model are the analyze stage, the design stage, the development stage, the implementation stage and the evaluation stage, but the implementation and evaluation stages are not carried out. The first stage in this research, namely the analyze stage is carried out by analyzing needs, curriculum analysis, analyzing student characteristics and analyzing good media. Needs analysis was conducted by conducting interviews with fourth grade teachers. Based on the results of the analysis, this interactive multimedia really needs to be developed and is suitable to be developed on the topic of class IV energy sources. The 
Design stage is done by making a media design. Design made using Photoshop CS6 application. The developed media is made using the articulate story line application 3 . The developed media is made using colorful pictures so that it attracts students' attention to the spirit of learning. To find out students' understanding of the material on the media, at the end it is equipped with a quiz as many as 10 quizzes. The following prototype of interactive multimedia-based learning media is presented in Table 03.

Table 3. Prototype of Interactive Multimedia-Based Learning Media

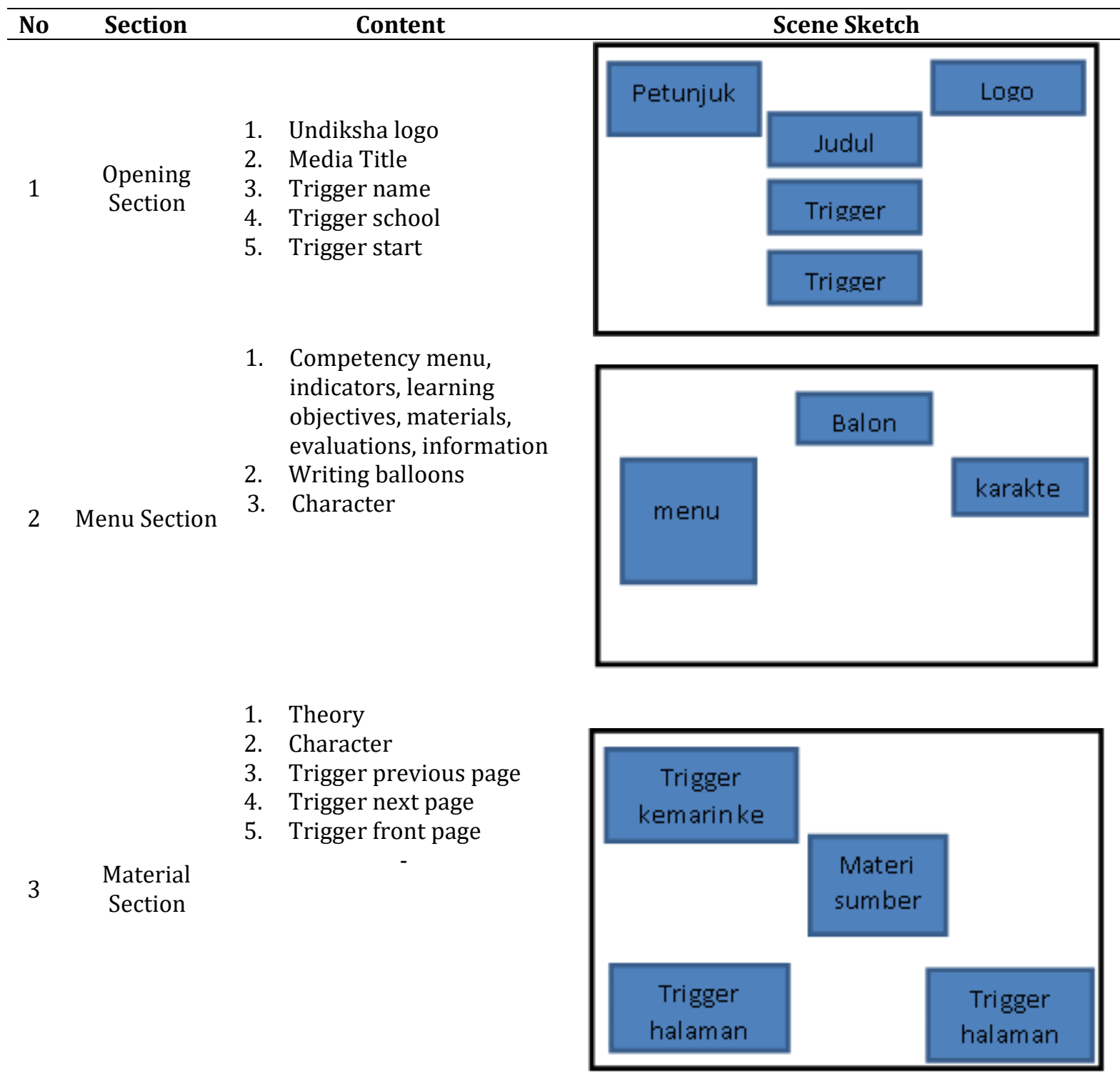




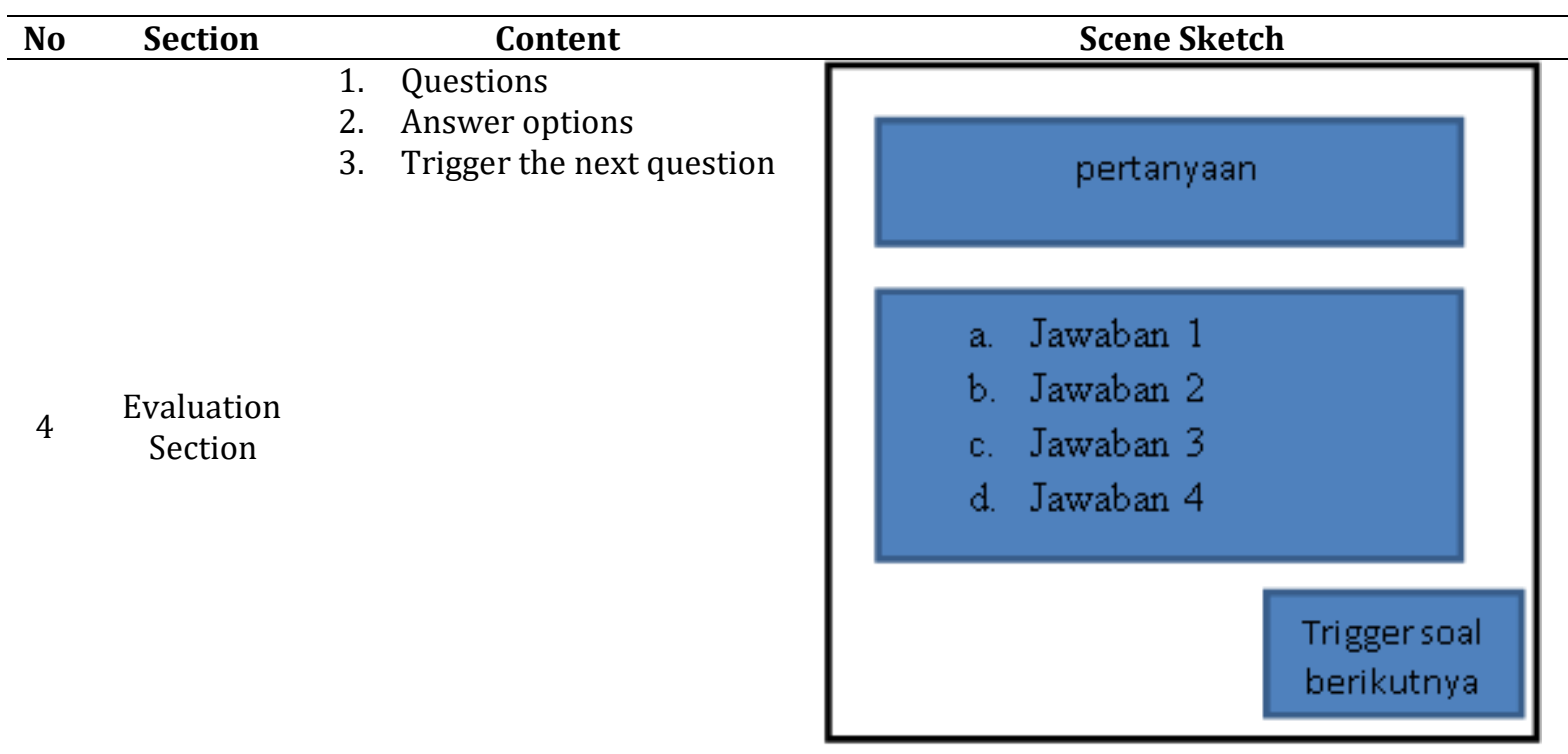

The development stage is carried out with media development. The media is developed according to the design that has been made. Making media adapts to needs analysis, curriculum analysis, material analysis that has been done previously. The media is made using the articulate storyline application 3 . After the media has been developed, it is assessed by 4 lecturers, 2 teachers and 9 students by providing media assessment sheets. This development research produces a product in the form of interactive multimedia-based learning media on the topic of energy sources for class IV Elementary School. Here are some media views that have been created.

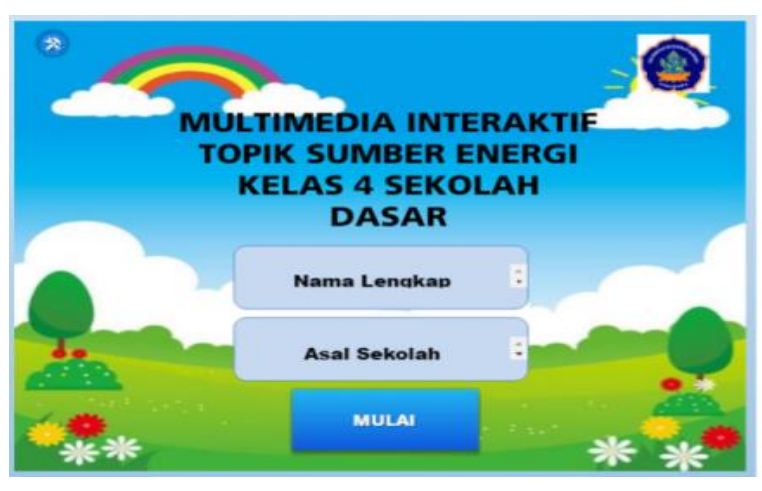

Figure 1. Opening Section

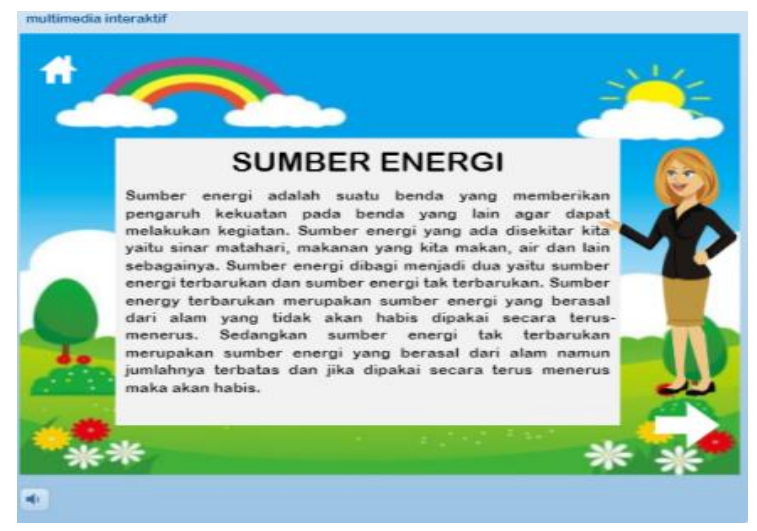

Figure 3. Material Section

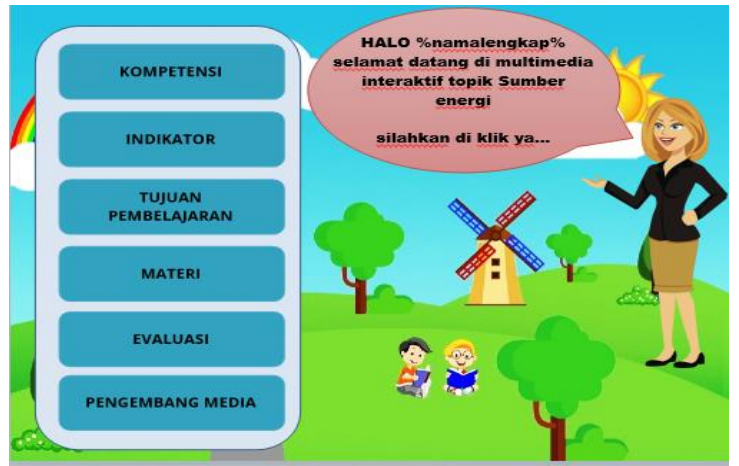

Figure 2. Menu Section

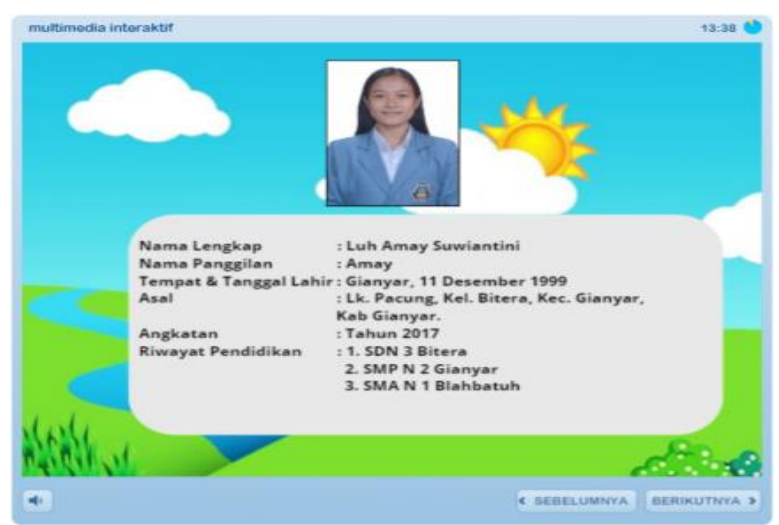

Figure 4. Developer Biodata Section 
Based on the assessments and inputs provided by material experts, media experts, design experts, practitioner experts as well as individual trials and small group trials, the results of the validity of interactive multimedia-based learning media on the topic of energy sources for grade IV elementary schools are presented in Table 4 and Table 5

Table 4. The Results of The Validity of Interactive Multimedia-Based Learning Media

\begin{tabular}{clcc}
\hline No & \multicolumn{1}{c}{ Respondent } & Value(\%) & Qualiffication \\
\hline 1 & Material Expert & 94,63 & Very good \\
2 & Media Expert & 93,33 & Very good \\
3 & Design Expert & 91,66 & Very good \\
4 & Practitioner Response & 91,66 & Very good \\
5 & Individual Trial & 96,11 & Very good \\
6 & Small Group Trial & 94,77 & Very good \\
\hline & Overall Percentage & $\mathbf{9 3 , 6 9}$ & Very Good \\
\hline
\end{tabular}

Table 5. Feedback, Suggestions and Comments from Experts

\begin{tabular}{cl}
\hline No & \multicolumn{1}{c}{ Feedback, Suggestions and Comments } \\
\hline 1 & At the beginning, use the undiksha logo which does not have a white background in the shape of \\
2 & Need instructions for using media \\
3 & Each benefit of solar energy is given an illustration image \\
4 & Wind energy source, avoid the background image to the text overlapping Karen blurring the text \\
5 & Add media developer identity or information replaced media developer \\
6 & Button when typed does not appear block box \\
7 & In the result section, a block is given to clarify the writing \\
8 & Larger font and font size dan \\
9 & Show it with more interesting material accompanied by pictures that support learning \\
\hline
\end{tabular}

Based on the results of media validation data analysis, material experts stated that the level of achievement of media development was in the Very good category. Judging from the aspects assessed in interactive multimedia-based learning media, namely the material aspects that discuss the suitability of the material with competencies, indicators and learning objectives, the quality of the material mediated and the relevance of the material. After validating the material expert, it was continued by validating the media expert who stated that the level of media development was in the very good category. Based on the assessed aspects, namely the quality of the media, the ease of using the media, the use of language. Furthermore, validation was carried out on design experts, based on the results of the validation the level of achievement of media development was categorized as very good, based on the aspects assessed, namely the appearance of the media such as the suitability of the image with the characteristics of the students, the attractiveness of the cover design, the compatibility of the writing color and the suitability of the image with the material being mediated. Then validated on 2 teachers at SD Negeri 1 Gianyar. The results of the validation by the teacher/practitioner stated that the level of achievement of media development was categorized as very good, based on the aspects assessed, namely the suitability of the material with competence, material quality, material relevance, media quality, media presentation, and media appearance. Furthermore, individual student trials were carried out to 3 students, the level of achievement of media development was categorized as very good. followed by a small group trial, it was found that the level of achievement of media development was categorized as very good, based on the aspect assessed, namely media presentation. In general, from the media validation, it is known that the level of achievement of interactive multimedia development on the topic of energy sources is categorized as very good so that it can be stated that interactive multimedia on the topic of energy sources is valid according to the multimedia elements both from audio media according to the characteristics of students, media visuals in the form of images in accordance with the material being mediated and interesting and motivating students to learn besides that it is also equipped with illustrations or animations so that the media display is more attractive. Experts also provide input and comments to improve the media for the better.

Based on the results of the analysis, interactive multimedia on the topic of energy sources in grade IV elementary schools has very good qualifications. This research produces interactive multimedia- 
based learning media on the topic of energy sources for grade IV Elementary Schools that are valid and suitable for use in elementary schools. This is in line with research which states that interactive multimedia is worthy of being used as learning media and is able to improve the quality of student learning (Wulandari et al., 2017) The results of this study are supported by research which states that interactive multimedia is appropriate for use in elementary schools and can be an alternative source of learning in the classroom (Fanny \& Suardiman, 2013). Subsequent research which states that the use of interactive multimedia in learning can liven up the classroom atmosphere, deliver more concrete material and increase student learning motivation (Hernaningtyas et al., 2016). The use of interactive multimedia can increase students' understanding ability (Purnamasari \& Herman, 2017). Media development is carried out according to the problems faced by the school and the needs and conditions in the school. The existence of interactive multimedia-based learning media is expected to help teachers in the learning process so that the material presented can be understood by students. The use of appropriate and good learning media will affect student learning outcomes, in addition to helping the teacher in delivering the material, the learning media also makes it easier for students to accept the material presented by the teacher (Savira \& Suharsono, 2013).

Many aspects affect the quality of education, one of which is the use of learning media that supports the learning process (Handhika, 2012). The application of interactive multimedia in schools can help students who have different learning styles because this media is a combined media of visual, audio, text, animation and video media. From this media students can learn by using pictures, music, videos and writing. The use of interactive multimedia is considered very appropriate to improve learning outcomes and optimize the teaching and learning process (Wulandari et al., 2017). The advantage of interactive multimedia is that it can combine various kinds of media and can also be used for independent and classical learning so that students with various levels of ability can use it without difficulty because it is equipped with instructions for use and interactive multimedia is also very practical to use because it can be accessed via computers or gadgets because it is distributed in the form of links. Based on the qualifications obtained, namely "very good", the interactive multimedia developed is feasible to be used as a learning medium for elementary school students. The implication of this research is the existence of interactive multimedia on the topic of energy sources in grade IV elementary schools with very good qualifications that have been tested for validity and are certainly suitable to be used as tools in the teaching and learning process in schools.

\section{Conclusion}

Based on the discussion above, it is known that interactive multimedia-based learning media that have been developed have very good qualifications seen from the suitability of the material, media quality and media presentation. Other researchers can continue the implementation stage and also the evaluation stage through experimental research.

\section{References}

Abdulrahaman, M. D., Faruk, N., Oloyede, A. A., Surajudeen-Bakinde, N. T., Olawoyin, L. A., Mejabi, O. V., Imam-Fulani, Y. O., Fahm, A. O., \& Azeez, A. L. (2020). Multimedia tools in the teaching and learning processes: A systematic review. Heliyon, 6(11), e05312. https://doi.org/10.1016/j.heliyon.2020.e05312

Akbar, N. S. (2016). Pengembangan Multimedia Pembelajaran Energi Alternatif. E-Jurnal Prodi Teknologi Pendidikan, $\quad V(6)$, http://journal.student.uny.ac.id/ojs/index.php/fiptp/article/view/3092/2788.

Ariantini, N. K. A., Rati, N. W., \& I Nyoman Murda. (2017). Pengaruh model pembelajaran think pair share terhadap hasil belajar ipa siswa kelas v sd gugus ii kecamatan melaya. E-Journal PGSD Universitas Pendidikan Ganesha, 5(2), 1-10. http://dx.doi.org/10.23887/jjpgsd.v5i2.10906.

Fanny, A. M., \& Suardiman, S. P. (2013). Pengembangan Multimedia Interaktif Untuk Mata Pelajaran Ilmu Pengetahuan Sosial (Ips) Sekolah Dasar Kelas V. Jurnal Prima Edukasia, 1(1), 1. https: //doi.org/10.21831/jpe.v1i1.2311.

Fuadi, Sumaryanto, T., \& Lestari, W. (2015). Pengembangan Instrumen Penilaian Aspek Psikomotor Pembelajaran Ipa Materi Tumbuhan Hijau Kelas V Berbasis Kompetensi Pendekatan Sea Berwawasan Konservasi. Journal of Research and Educational Research Evaluation, 4(1), 53-63. https: //doi.org/10.15294/jere.

Gallagher, C. (2019). The use of a multimedia case to prepare classroom teachers of emergent bilinguals. Teaching and Teacher Education, 84, 17-29. https://doi.org/10.1016/j.tate.2019.04.011. 
Handhika, J. (2012). Efektivitas media pembelajaran im3 ditinjau dari motivasi belajar. Jurnal Pendidikan IPA Indonesia, 1(2), 109-114. https://doi.org/10.15294/jpii.v1i2.2127.

Hernaningtyas, I. S., Susetyarini, R. E., \& Widodo, R. (2016). Pengembangan Multimedia Interaktif Ceria (Mic) Pembelajaran Tematik Di Sekolah Dasar. Jurnal Pemikiran Dan Pengembangan Sekolah Dasar (JP2SD), 1(4), 256. https://doi.org/10.22219/jp2sd.vol1.no4.256-266.

Huang, S. Y., Kuo, Y. H., \& Chen, H. C. (2020). Applying digital escape rooms infused with science teaching in elementary school: Learning performance, learning motivation, and problem-solving ability. Thinking Skills and Creativity, 37(April), 100681. https://doi.org/10.1016/j.tsc.2020.100681.

Irfan, I., Muhiddin, M., \& Ristiana, E. (2019). Pengembangan Media Pembelajaran IPA Berbasis Powerpoint di Sekolah Dasar. Indonesian Journal of Primary ..., 3(2), 16-27. https://ejournal.upi.edu/index.php/IJPE/article/view/21765.

Khan, F. M. A., \& Masood, M. (2015). The Effectiveness of an Interactive Multimedia Courseware with Cooperative Mastery Approach in Enhancing Higher Order Thinking Skills in Learning Cellular Respiration. Procedia - Social and Behavioral Sciences, 176, 977-984. https://doi.org/10.1016/j.sbspro.2015.01.567.

Kornmann, J., Kammerer, Y., Zettler, I., Trautwein, U., \& Gerjets, P. (2016). Hypermedia exploration stimulates multiperspective reasoning in elementary school children with high working memory capacity: A tablet computer study. Learning and Individual Differences, 51, 273-283. https://doi.org/10.1016/j.lindif.2016.08.041.

Laksana, D. N. L. (2016). Miskonsepsi Dalam Materi Ipa Sekolah Dasar. JPI (Jurnal Pendidikan Indonesia), 5(2), 166. https://doi.org/10.23887/jpi-undiksha.v5i2.8588.

Lee, T. T., \& Osman, K. (2012). Interactive Multimedia Module in the Learning of Electrochemistry: Effects on Students' Understanding and Motivation. Procedia - Social and Behavioral Sciences, 46, 13231327. https://doi.org/10.1016/j.sbspro.2012.05.295.

Lewis, A. D. (2019). Practice what you teach: How experiencing elementary school science teaching practices helps prepare teacher candidates. Teaching and Teacher Education, 86, 102886. https://doi.org/10.1016/j.tate.2019.102886.

Paratore, J. R., O’Brien, L. M., Jiménez, L., Salinas, A., \& Ly, C. (2016). Engaging preservice teachers in integrated study and use of educational media and technology in teaching reading. Teaching and Teacher Education, 59, 247-260. https://doi.org/10.1016/j.tate.2016.06.003.

Pariartha, I. G. M. A., Parmiti, D. P., \& Sudatha, I. G. W. (2013). Pengembangan Media Pembelajaran Berbasis Multimedia Interaktif Pada Mata Pelajaran Ipa Untuk Siswa Kelas Viii Semester 1 Di Smp Negeri 3 Singaraja Tahun Pelajaran 2012/2013. Jurnal EDUTECH Undiksha, 1(2). http://dx.doi.org/10.23887/jeu.v1i2.938.

Prabawa, D. G. A. P., \& Restami, M. P. (2020). Pengembangan Multimedia Tematik Berpendekatan Saintifik untuk Siswa Sekolah Dasar. Mimbar PGSD Undikhsa, 8(3), 479-491. https://ejournal.undiksha.ac.id/index.php/JJPGSD\%0APengembangan.

Pujiastuti, D., Idrus, A., \& Emosda. (2014). Pengembangan Media Pembelajaran Pkn Berbasis Multimedia Interaktif Untuk SMP Kelas VIII. Tekno-Pedagogi, 4(1), 1-6. https://onlinejournal.unja.ac.id/pedagogi/article/view/2245.

Purnamasari, S., \& Herman, T. (2017). Penggunaan Multimedia Interaktif Terhadap Peningkatan Kemampuan Pemahaman Dan Komunikasi Matematis, Serta Kemandirian Belajar Siswa Sekolah Dasar. EduHumaniora / Jurnal Pendidikan Dasar Kampus Cibiru, 8(2), 178. https://doi.org/10.17509/eh.v8i2.5140.

Putri, S. U. (2015). Penerapan pendekatan. Metodik Didaktik, 10(1), 69-77. https://doi.org/10.17509/md.v10i1.3231.

Rahayu, P., Mulyani, S., \& Miswadi, S. S. (2012). Pengembangan pembelajaran IPA terpadu dengan menggunakan model pembelajaran problem base melalui lesson study. Jurnal Pendidikan IPA Indonesia, 1(1), 63-70. https://doi.org/10.15294/jpii.v1i1.2015.

Rante, P., Sudarto, \& Ihsan, N. (2013). Pengembangan multimedia pembelajaran fisika berbasis audiovideo eksperimen listrik dinamis di smp. Jurnal Pendidikan IPA Indonesia, 2(2), 203-208. https://doi.org/10.15294/jpii.v2i2.2724.

Riani, S., Hindun, I., \& Krisno Budiyanto, M. A. (2015). Pengembangan Media Pembelajaran Berbasis Multimedia Interaktif Untuk Meningkatkan Pemahaman Materi Bioteknologi Modern Siswa Kelas Xii Sma. Jurnal Pendidikan Biologi Indonesia, 1(1), 9-16. https://doi.org/10.22219/jpbi.v1i1.2298.

Saifudin, M. F., Susilaningsih, \& Wedi, A. (2020). Pengembangan multimedia interaktif materi sumber energi untuk memudahkan belajar siswa sd. Jurnal Kajian Teknologi Pendidikan, 3(1), 68-77. https: //core.ac.uk/download/pdf/287323706.pdf.

Savira, F., \& Suharsono, Y. (2013). Pengaruh Penggunaan Media Pembelajaran Terhadap Hasil Belajar 
Siswa Pada Mata Pelajaran Ekonomi Di Sma. Journal of Chemical Information and Modeling, 01(01), 1689-1699.

Sofyan, R., WS, R., \& Ghullam Hamdu. (2016). Thematic learning media development based interactive multimedia. 272-280. https://ejournal.upi.edu/index.php/pedadidaktika/article/view/5157

Ucus, S. (2015). Elementary School Teachers' Views on Game-based Learning as a Teaching Method. Procedia - Social and Behavioral Sciences, 186, 401-409. https://doi.org/10.1016/j.sbspro.2015.04.216.

Widayat, W., Kasmui, \& Sukaesih, S. (2014). Pengembangan Multimedia Interaktif Sebagai Media Pembelajaran Ipa Terpadu Pada Tema Sistem Gerak Pada Manusia. USEJ - Unnes Science Education Journal, 3(2), 535-541. https://doi.org/10.15294/usej.v3i2.3353.

Wulandari, R., Susilo, H., \& Kuswandi, D. (2017). Penggunaan multimedia interaktif bermuatan game edukasi untuk siswa sekolah dasar. Jurnal Pendidikan: Teori , Penelitian Dan Pengembangan, 2(8), 1024-1029. http://journal.um.ac.id/index.php/jptpp/article/view/9759/4611.

Yakovleva, Y. V., \& Goltsova, N. V. (2016). Information and Communication Technologies as a Means of Developing Pupils' Learning Motivation in Elementary School. Procedia - Social and Behavioral Sciences, 233(May), 428-432. https: //doi.org/10.1016/j.sbspro.2016.10.179. 